IZA DP No. 8349

Transitions in a West African Labour Market: The Role of Family Networks

Christophe J. Nordman

Laure Pasquier-Doumer

July 2014 


\title{
Transitions in a West African Labour Market: The Role of Family Networks
}

\author{
Christophe J. Nordman \\ IRD, DIAL and IZA \\ Laure Pasquier-Doumer \\ IRD, DIAL
}
Discussion Paper No. 8349
July 2014

IZA
P.O. Box 7240
53072 Bonn
Germany

Phone: +49-228-3894-0

Fax: +49-228-3894-180

E-mail: iza@iza.org

\begin{abstract}
Any opinions expressed here are those of the author(s) and not those of IZA. Research published in this series may include views on policy, but the institute itself takes no institutional policy positions. The IZA research network is committed to the IZA Guiding Principles of Research Integrity.

The Institute for the Study of Labor (IZA) in Bonn is a local and virtual international research center and a place of communication between science, politics and business. IZA is an independent nonprofit organization supported by Deutsche Post Foundation. The center is associated with the University of Bonn and offers a stimulating research environment through its international network, workshops and conferences, data service, project support, research visits and doctoral program. IZA engages in (i) original and internationally competitive research in all fields of labor economics, (ii) development of policy concepts, and (iii) dissemination of research results and concepts to the interested public.
\end{abstract}

IZA Discussion Papers often represent preliminary work and are circulated to encourage discussion. Citation of such a paper should account for its provisional character. A revised version may be available directly from the author. 


\section{ABSTRACT}

\section{Transitions in a West African Labour Market: The Role of Family Networks}

This paper sheds light on the role of family networks in the dynamics of a West African labour market, i.e. in the transitions from unemployment to employment, from wage employment to self-employment, and from self-employment to wage employment. It investigates the effects of three dimensions of the family network on these transitions: its structure, the strength of ties and the resources embedded in the network. For this purpose, we use a first-hand survey conducted in Ouagadougou on a representative sample of 2000 households. Using event history data and very detailed information on family network, we estimate proportional hazard models for discrete-time data. We find that family networks have a significant effect on the dynamics of workers in the labour market and that this effect differs depending on the type of transition and the considered dimension of the family network. The network size appears to not matter much in the labour market dynamics. Strong ties however play a stabilizing role by limiting large transitions. Their negative effect on transitions is reinforced with high level of resources embedded in the network.

JEL Classification: D13, J24, L14

Keywords: family network, labour market dynamics, event history data, survival analysis, Burkina Faso

Corresponding author:

Christophe J. Nordman

IRD, DIAL

4 rue d'Enghien

75010 Paris

France

E-mail: nordman@dial.prd.fr 


\section{Introduction}

A recent economic literature emphasizes the importance of social networks in labour market outcomes by conveying information about employment, market opportunities or new technology (Durlauf and Fafchamps 2005; Ioannides and Loury 2004). From a theoretical perspective, social networks are known to be crucial to understand the dynamics of labour market, in particular duration dependence and persistence in unemployment (Calvó-Armengol and Jackson 2004, 2007; Bramoullé and Saint-Paul 2010). From an empirical perspective, evidence shows that there is a widespread use of friends, relatives, and other acquaintances to search for jobs and to access coveted positions. For entrepreneurs, social networks may be used to reduce the uncertainties they face regarding market opportunities, reliance of partners, or productivity of their prospective employees, and also to enhance risk-sharing and informal credit arrangements (Hoang and Antoncic 2003). Within the social network, family ties have been shown to play a key role in labour market outcomes (Granovetter 1995), by enforcing informal agreements (La Ferrera 2007) It has also recently been shown that fresh graduates benefit from the use of family ties (parents) through faster access to jobs and by better labour market outcomes (Kramarz and Skans 2013).

These issues are decisive in developing countries where a large part of inefficiency in the labour market may be due to imperfect information. These countries are often characterized by a lack of formal institutions channeling information about jobs or market opportunities. In Ouagadougou (Burkina Faso) for example, 85 percent of unemployed workers are not registered in the public employment office and 45 percent of them declare that this is because they do not know it does exist (DIAL 2007). In the absence of formal institutions, the role played by interpersonal relationships and in particular by the family network may then be substantial in employment trajectories.

While there is strong evidence on the importance of social and family networks in labour markets in developing countries, little is known in these countries about the specific effect of different 
dimensions of these networks. Indeed, most of the studies in developing countries, particularly in Sub-Saharan Africa, focus on the size of networks, approximated by the number of contacts that an agent maintains with other categories of agents. However, since the seminal sociological work of Granovetter (1973), it is widely acknowledged that the intensity of ties is an essential dimension of social networks. Granovetter brought out 'the strength of weak ties' argument highlighting that links with infrequent interactions or with low intimacy, the weak ties, tend to bridge individuals across social groups of close interpersonal relationships, and are consequently the most informative and the most useful in the labour market. Following Granovetter's definition of the strength of ties, strong as well as weak ties can be observed even among family members. Lin (1990)'s theory of social resources also emphasizes a dimension of social networks that has to be addressed: the resources available in a network, defined by the socio-economic characteristics of the individuals connected through the network.

Some studies have attempted to fill this knowledge gap but they remain divided on the effect of social networks resources and ties content on the labour market. Besides, they mostly focus on enterprises outcomes (such as Barr 2002) and they do not address the issue of dynamics of employment. An interesting exception is Kramarz and Skans (2013) who use a Swedish linked employer-employee data set to show that strong social ties (parents) are an important determinant for where young workers find their first job but also for progressing in their career. For Africa, using a longitudinal dataset on young South Africans to examine the correlation of children's employment with parents' usefulness in job search, Magruder (2010) finds that fathers serve as useful network connections to their sons (but not daughters), contrary to mothers. Relying an original dataset collected in the informal economy of Bobo-Dioulasso (Burkina Faso), Berrou and Combarnous (2012) argue that informal entrepreneurs have to combine strong and wide ongoing social support ties with weaker business ties to be successful. In the West-African context again, Pasquier-Doumer (2013) has shown that informal entrepreneurs who have family members involved in the same activity have better performance. 
Other studies emphasize the reverse side of strong ties. In her research on informal manufacturers in Nigeria, Meagher (2006) identifies disinclination among entrepreneurs to trade with people from their home communities because they exercise moral pressure to get credit and then expect the trader to understand their problems when the time comes for repayment. In the same way, Whitehouse (2011) find that in the capital of the Republic of Congo, it is especially difficult for entrepreneurs to do business in their home communities, where they face a constant barrage of requests by their kin, both close and distant, for goods on credit, for discounts, for employment, and for short-term loans or grants outright. For informal entrepreneurs in West Africa, including in Ouagadougou, Grimm et al. (2013) provide evidence that, while family and kinship ties within the city rather enhance labour effort and the use of physical capital, distant kinship ties can be source of pressure to redistribution that prevent their economic success.

Hence, family networks may affect workers' dynamics in different ways and there is no clear evidence on which is the main channel. This lack of consensus may be explained by the low representativeness level of data in Africa, but also because most studies fail to overcome the simultaneity issue between network constitution and workers' dynamics. ${ }^{1}$ Another difficulty is to be able to determine which features of the networks interact the most with workers' trajectories, and through which channel, this requiring detailed characteristics of these family networks.

In a West African context, this paper aims at disentangling the determinants of changes in the workers' employment status and transitions from unemployment to employment by emphasizing the role played by family networks in stabilizing or helping workers enhancing their professional situation. A crucial question tackled is to what extent and why different sorts of family networks may lead to different employment trajectories. We analyze the effect of family networks on specific employment transitions in Ouagadougou by answering the following questions. Do

\footnotetext{
${ }^{1}$ Simultaneity bias in estimations may occur when workers build their network through various strategies in order to enhance their occupational trajectories.
} 
family ties help unemployed individuals access employment? To what extent is personal family network essential in the transition from wage employment to self-employment or from selfemployment to wage employment? Indeed, using the divide of self- and wage-employment in urban West Africa has been shown to be a meaningful way of characterizing the quality and vulnerability of jobs (Bocquier et al. 2010).

We attempt to overcome the limitations of the previous studies on social networks and labour markets outcomes in Sub-Saharan Africa in different ways. First, we avail ourselves of a representative sample of households in the capital of Burkina Faso which combines workers' socio-demographic and very detailed social network information together with event history data, in particular the individuals' employment records. ${ }^{2}$ Second, we characterize the family networks in their various dimensions. Lastly, we address the problem of simultaneity bias that may affect the measure of the effect of networks on labour market outcomes by using a survival analysis that makes use of proportional hazard models for discrete-time data, and by relying mostly on the characteristics of the sibling to define family network.

The paper is organized as follows. Section 2 presents the data and the concepts used. Section 3 summarizes the estimation strategy. Section 4 comments on the effect of family networks on professional transitions and Section 5 concludes.

${ }^{2}$ See Nordman and Roubaud (2009) for an example of labour market analysis using event history data. 


\section{Surveys, data and definitions}

\section{The surveys}

For this analysis, we use an original survey conducted in 2009 in Ouagadougou on a representative sample of 2000 households. This survey was conducted by a team of researchers from the French Institute of Research for Development (IRD), including the authors of this paper, under the supervision of Daniel Delaunay and Florence Boyer (Boyer and Delaunay 2009). This survey provides data on socio-demographic characteristics of the households and their members and also on individual events such as work experience and migration history. In addition, the survey includes very detailed information on social networks that we will describe below. An area sampling methodology guarantees the representativeness of the survey. ${ }^{3}$ Event history and social network information were collected among half of the individuals aged 18 and over, chosen at random. ${ }^{4}$ Thus, we collected work histories of 1762 men and 1050 women totaling 2812 individuals. $^{5}$

In addition, following the approach advocated in Kanbur (2005), qualitative data are used in our analysis to complement the quantitative results. In April 2009, 15 qualitative interviews were carried out with individuals having responded to the full questionnaires. ${ }^{6}$ The interviews were semi-structured, following the event history questionnaire, and a comprehensive interviewing guide in order to streamline the reporting and recording of the narratives. The emphasis was placed on the social network formation and dynamics of the interviewees, on the resources they had acquired over their life span (social capital, human capital and financial capital), on the help

\footnotetext{
${ }^{3}$ In a first step, we have set the limits of the city. Then, the city was divided into small sub-areas which were randomly sampled. Each of the chosen sub-areas was then fully inspected and enumerated, and one of the households of the sub-area was chosen at random. All the individuals of the household were surveyed.

${ }^{4}$ For more details, see Boyer and Delaunay (2009).

${ }^{5}$ Weights are applied in all calculations to take into account the sampling scheme.

${ }^{6}$ Using the sampling frame of the 'quantitative' survey on households, the sampling of respondents, whose interviews took place at the respondents' home and/or workplace, intended to include individuals with diverse characteristics regarding specifically their occupations, professional and migration experiences.
} 
they had received at different stages of their trajectories (schooling, marriage, housing, job), and on the process of professional insertion and transitions. The duration of the interviews varied between 45 minutes and one hour and a half.

\section{Defining and measuring family network characteristics}

Following the 'egocentered' perspective, social network is defined as a set of human contacts ("alters") known to an individual ("Ego"), by whom he/she expects to share material or intangible resources. In this paper, we focus on family ties. Using the family as a measure of social network is a way to tackle issues of endogeneity and timing, making the assumption that the size of the family is not subject to endogenous changes over the individuals' professional life. Indeed, it is recognized in the literature in economics that family ties with actual genealogical ties can be seen as largely exogenous and cannot be freely changed or only at a high psychological cost (La Ferrara 2007). In addition, some studies show that family ties are crucial for professional activity in the Sub-Saharan African context: at the start of an enterprise, but also to face a professional shock (Berrou and Combarnous 2012; Pasquier-Doumer 2013; Fafchamps 2002; Lourenço-Lindell 2002). In our survey, family ties represent 60 percent of all the support received to find a job or to improve the current professional activity (Pasquier-Doumer 2010). Family, in particular the siblings, may then be a good proxy of social networks as far as transitions on the labour market are concerned.

The size of networks is considered in this paper together with their ties contents and resources dimension. Most of them were measured with a name-generating methodology in the 'quantitative' survey (McCallister and Fischer 1978). More precisely, the respondents were asked to cite all their siblings from the same mother and father who were currently alive ${ }^{7}$. Further

\footnotetext{
${ }^{7}$ We decide to restrict to siblings and not to use the extended family as a measure of the social network, such as cousins, uncles and aunts. This is because we do not capture the actual blood relationships of the respondents with other parents quite perfectly. This problem is worsened by the fact that many communities of migrants in West Africa call each other 'cousins' (for example the large Ivorian diaspora in Burkina Faso). Then, not being able to take
} 
questions included in a name interpreter provided information about the characteristics of the cited person. From this information, we could reconstruct the strength of ties as well as the resources embedded in the family network, captured by the socioeconomic statuses of those cited. These name generators allowed us to collect information on 11,017 siblings.

Three types of social network variables are finally computed to characterize the network in its three main dimensions, i.e. structure, resources and strength of ties: (1) the number of siblings that aims at characterizing one dimension of the structure, the network size of Ego, also called the degree of a node (Jackson 2008); (2) the average years of schooling of the siblings and dummies taking value one if a member of the siblings has a job in the public sector, which is supposed to capture the resources embedded in one's family network; (3) three variables aiming at reflecting the strength of ties, defined by Granovetter (1973, p.1361) as a "combination of the amount of time, the emotional intensity, the intimacy (mutual confiding), and the reciprocal services which characterize the tie": an index of the geographical remoteness of the siblings to Ouagadougou ${ }^{8}$, and the geographical distance from Ouagadougou to the worker's locality, village or province of origin ${ }^{9}$, assuming that a longer distance makes it more difficult and costly to keep in touch with the family and the kin (an 'out of sight, out of mind' effect), hence that the intensity of the ties declines with distance (Gubert and Fafchamps 2007; Whitehouse 2011); and a dummy taking

into account true blood relationships may worsen the potential endogeneity of the link between social networks and labour market outcomes. Yet, an issue with the sibling size is the possible existence of differential mortality, i.e. diverging expectations of life for different age cohorts: older cohorts of workers may have lost more brothers and sisters than younger generations of workers at the same age. Differential mortality may affect other characteristics of the siblings such as its average level of education, its occupational status or its geographical fragmentation. To check for this possible phenomenon in the characteristics of the siblings, we account for age and use crossed age-siblings effects in the regressions to determine to what extent this may affect our estimates.

${ }^{8}$ This index takes the value 1 if all the siblings live in Ouagadougou and more than half live in the same sector of the city than the respondent, 2 if the siblings live in Ouagadougou and less than half live in the same sector of the city than the respondent, 3 if all the siblings live in Burkina Faso and more than half in Ouagadougou, 4 if all the siblings live in Burkina Faso and less than half in Ouagadougou, 5 if more than half of the siblings live in Burkina, 6 if less than half of the siblings live in Burkina Faso.

${ }^{9}$ For this variable, instead of relying on a geographical distance per se calculated in kilometers (that can be computed from Ouagadougou to the village or commune of origin using geographical maps), we collected directly information from the main bus stations of Ouagadougou about the time and costs necessary to reach the closest main city in the corresponding province of Burkina Faso. This ensures that we are effectively approaching a (time or monetary) cost to keep in touch with the remote family, in a context where roads could be in very different conditions. 
value one if the individual visited a family member at least once over the past week ${ }^{10}$, which aims at reflecting the reciprocal dimension of ties. However, the exogenous status of the latter variable may be questionable. The variable related to visits to parents is potentially endogenous to changes in the employment status if these visits aimed at showing gratitude to parents who supported Ego when the occupational change occurred. Yet, the time interval between the observation of the visits (one week before the survey) and the employment transition is very large (12 years on average), which makes us believe that this variable is not endogenous to previous labour market choices, as far as we assume that visits to show gratitude would decrease with time. Indeed, many other events have occurred that may have shaped the strength of the ties. We then consider the visit dummy as a structural measure of strength of family ties.

Regarding the use of the variable of geographical distance from Ouagadougou to the worker's locality, village or province of origin - which is deemed to reflect the intensity of the individuals' relationship with their family network, one could object that it may not affect transitions if such transitions precisely occurred before the workers arrived in Ouagadougou, so prior to their migration. We checked this possibility and found that employment transitions taking place outside Ouagadougou concerned only 5 percent of workers who experienced a transition, so that this argument does not invalidate the use of such distance variable. Another problem with the use of geographical distance could be that high ability workers may be more likely to move to urban areas and, even more problematically, may be willing to migrate further. ${ }^{11}$ In such case, distance may be correlated with unobserved characteristics of the workers and might just pick up the effect of abilities in the regressions. We limit this possibility by relying on 'frailty' models which

\footnotetext{
${ }^{10}$ The survey includes an entire module that aims at measuring all the travels of the respondent during a week.

${ }^{11}$ The following argument mitigates the potential bias however. We consider non-migrants and migrants who only decided to migrate to the economic capital of Burkina Faso. One may then assume that this decision to migrate is often taken whatever the distance to the capital is. In other words, migrants do not so much choose between places of different distance to their home, but rather whether they migrate to one of the secondary cities or to the economic capital. Hence, one may argue that all those who migrated and opted for the economic capital share similar unobservable characteristics implying a relatively small potential bias associated with our distance measure between them.
} 
consist of modeling the unobserved heterogeneity component thanks to the structure of the event history data (see Section 3).

\section{Measuring labour market transitions}

Labour market transitions are measured using work histories. In the work histories, individuals have been asked about their spells of activity and inactivity. Events are declared on an annual basis, so that we do not precisely know the months of the event occurrence. Spells are then converted into durations which are computed in years. Each spell of activity was then characterized by the status of activity (employed versus unemployed), the type of employment (self-employment, wage employment, other), the sector of activity and the type of enterprise (public versus private).

Three different labour market transitions, called 'failure' thereafter (see Section 3), are examined in this paper. The first one is the transition from unemployment to employment (1). The two other transitions can be described as changes in the worker's employment status: wage employment to self-employment (2), and self-employment to wage employment (3). Let us briefly describe how we defined the different employment changes.

For some individuals, there has been some time out of employment or of the labour market. Should this be included or not in the record of employment changes? Kambourov and Manovskii (2008) argue that excluding career breaks would underestimate changes. However, the relationship between job changes and breaks in employment probably varies by gender, as the change of occupation for women is often a secondary outcome of a different decision, in particular that of child rearing. As a result, some authors exclude women from their sample (Kambourov and Manovskii 2008). Other authors keep men and women in the sample but compensate by excluding employment interruptions (Parrado, Caner and Wolff 2007), which may 
distort their results. In this paper, we made the choice of excluding women from the analysis. ${ }^{12}$ The principal reason for this is that the number of women having known a labour market transition is very small in our sample, which would lead us to estimating very small hazard rates for this category of workers ${ }^{13}$ (see the distribution of event occurrences for men and women in Table 1). Another reason is that the survey we use is not a labour force survey (LFS), which would allow identifying activity and inactivity spells with accuracy thanks to the use of a series of appropriate filter questions. Hence, distinction between unemployment and inactivity periods, for instance, is particularly prone to be identified with errors for women in our survey since women usually have less labour force attachment than men.

Table 1. Characteristics of Transitions, by Sex

\begin{tabular}{|c|c|c|c|}
\hline Labour Market Transitions & $\begin{array}{c}\text { Number of } \\
\text { spells }\end{array}$ & $\begin{array}{c}\text { Number of event } \\
\text { occurrences } \\
\text { (failures) }\end{array}$ & $\begin{array}{l}\text { Mean length in } \\
\text { years if failure }\end{array}$ \\
\hline \multicolumn{4}{|c|}{ (1) Unemployment to employment } \\
\hline Overall & 786 & 322 & 12.2 \\
\hline Men & 228 & 118 & 6.2 \\
\hline Women & 558 & 204 & 15.6 \\
\hline \multicolumn{4}{|c|}{ (2) Wage employment to self-employment } \\
\hline Overall & 1250 & 181 & 9.9 \\
\hline Men & 999 & 168 & 9.9 \\
\hline Women & 251 & 13 & 8.8 \\
\hline \multicolumn{4}{|c|}{ (3) Self-employment to wage employment } \\
\hline Overall & 1347 & 130 & 12.2 \\
\hline Men & 918 & 119 & 12.5 \\
\hline Women & 429 & 11 & 9.1 \\
\hline
\end{tabular}

Source: Ouaga2009 survey, authors' calculation

\footnotetext{
${ }^{12}$ To check for the existence of gender-specific effects in our results, we still ran regressions for men and women separately, in particular concerning the transition from unemployment to employment where the number of failures is sufficiently large for women. For employment changes regressions, we preferred to use interaction terms with the sex dummy variable because the occurrence of job changes is very low for women, and so segmenting the global sample by sex would consist of estimating a very small probability of failure in many cases. The results of these exercises are not discussed in this paper for lack of space but are available from the authors upon request.

${ }^{13}$ See the hazard model presented in Section 3.
} 
In addition, as in Mc Keever (2006), we ignore non-consecutive changes in employment status, that is to say transitions that were interrupted by a (long) period of unemployment or inactivity. We do this in order to obtain net estimates of the family network determinants of transitions between jobs, i.e. net from the determinants resulting from transitions between inactivity (or unemployment) to new jobs, the latter transitions having different interpretations in terms of the social network mobilized. In so doing, the drawback is that we may ignore transitions that were preceded by short withdrawals from activity, i.e. those transitions which were unavoidably broken up by frictional unemployment, that is by the time to get information about new jobs and to mobilize the social network. In order to keep such transitions in the sample, we still consider as 'consecutive' transitions between two jobs those that are interrupted by at most two years of unemployment or inactivity. This allows recovering frictional transitions, but still neglects longterm labour market withdrawals (or unemployment of discouraged workers). ${ }^{14}$

Finally, we treat each respondent's job spell as a separate case for analysis, meaning that the observation unit is transitions or changes in employment status, not individuals.

Table 2 provides descriptive statistics of workers having known the three types of transitions. Looking at the first transition from unemployment to employment, two social network features diverge significantly between workers who experienced such a transition and those who did not experience it at the time of the survey ('failure' versus 'no failure', see the hazard model presented in Section 3), both related to network structure. Unemployed workers who experienced a transition to employment have a larger family network: they declare having on average 4 siblings, while unemployed workers who did not experience such transition declare 2.9 siblings. However,

\footnotetext{
${ }^{14}$ Modeling unemployment duration jointly with the specific state exited into rather than duration alone would be an interesting path of research (Lancaster 1990; Carrasco 1999). Considering these competing risk models implies to not exclude from the sample non-consecutive changes in employment status. However, we chose to not follow this path of research, as we are constrained by low numbers of specific transitions (self-employment or wage employment) to and from unemployment.
} 
it is premature to conclude at this stage that family network capital fosters job access in the labour market.

If we then compare wage workers who evolve in this status with wage workers who transit to self-employment (Column (2)), we observe high differences between these two types of workers: wage workers without transition are on average younger, more educated and richer than wage workers who become self-employed. They work more often in the public sector (34 percent are in the public sector compared with 12 percent for those who become self-employed). They are involved in a larger family network with higher resources. Lastly, they maintain weaker ties with their kinship, as measured by the distance to the birthplace. However, we do not know whether this last result is due to the existence of a selection effect of migration. In addition, most of wage workers having experienced a transition have become self-employed while they were already living in Ouagadougou. For the majority, the transition has not occurred because of the Structural Adjustment Programme or the devaluation of the CFA francs in 1994.

Differences between self-employed workers who transit to wage employment and self-employed workers without transition are weaker. The former are older and more often migrant, although the transition occurred 11 years on average after migration to Ouagadougou. Self-employed workers who transit to wage employment have also a poorer network in terms of resources.

To conclude, we attempted to hierarchize the employment transitions. Due to data limitations, we cannot clearly infer a welfare gain for each transition, expect for the transition of unemployment to employment. However, using Ego's average level of education and average level of wealth, we can highlight general trend. Workers who evolve in wage employment are on top of the socio-economic ladder and benefit from a large social network with high resources. At the bottom of the socio-economic ladder are the self-employed workers who have become wage workers. They are also those with the narrower and less endowed in resources social network. 
Self-employed workers without transition and wage workers who became self-employed fall between these two extremes, without clear distinction between the two.

Table 2. Characteristics of Workers by Transitions

\begin{tabular}{|c|c|c|c|c|c|c|c|c|c|}
\hline \multirow[b]{2}{*}{ Characteristics } & \multicolumn{3}{|c|}{$\begin{array}{l}\text { (1) Unemployment to } \\
\text { employment }\end{array}$} & \multicolumn{3}{|c|}{$\begin{array}{c}\text { (2) Wage } \\
\text { employment to self- } \\
\text { employment }\end{array}$} & \multicolumn{3}{|c|}{$\begin{array}{c}\text { (3) Self-employment } \\
\text { to wage } \\
\text { employment }\end{array}$} \\
\hline & $\begin{array}{l}\text { No } \\
\text { failure }\end{array}$ & Failure & Sig & $\begin{array}{l}\text { No } \\
\text { failure }\end{array}$ & Failure & Sig & $\begin{array}{l}\text { No } \\
\text { failure }\end{array}$ & Failure & Sig \\
\hline Individual characteristics & & & & & & & & & \\
\hline Average age & 42.13 & 38.29 & & 40.48 & 47.87 & $* *$ & 38.75 & 46.51 & $* *$ \\
\hline Dummy for Islam & 0.61 & 0.64 & & 0.47 & 0.54 & & 0.65 & 0.55 & \\
\hline Dummy for Moore & 0.84 & 0.75 & & 0.74 & 0.91 & $* *$ & 0.88 & 0.87 & \\
\hline Dummy for born in Ouagadougou & 0.21 & 0.35 & & 0.22 & 0.23 & & 0.29 & 0.14 & $* *$ \\
\hline Dummy for primary school or less & 0.48 & 0.26 & $* *$ & 0.30 & 0.61 & $* *$ & 0.56 & 0.63 & \\
\hline Years of schooling & 4.49 & 6.48 & $* *$ & 7.38 & 2.89 & $* *$ & 3.27 & 2.36 & \\
\hline Standard of living index in 2009 & -0.19 & 0.09 & & 0.18 & -0.32 & $* *$ & -0.35 & -0.53 & \\
\hline Individual characteristics at failure time & & & & & & & & & \\
\hline Potential experience (years) & & 8.97 & & & 15.15 & & & 17.00 & \\
\hline Dummy for living in Ouaga & & 0.92 & & & 0.81 & & & 0.84 & \\
\hline Time since arrival in Ouaga (years) & & 16.02 & & & 15.61 & & & 11.39 & \\
\hline Time since first child birth (years) & & 2.41 & & & 4.30 & & & 5.21 & \\
\hline Dummy for failure before the devaluation & & 0.27 & & & 0.56 & & & 0.45 & \\
\hline Activity characteristics before failure & & & & & & & & & \\
\hline $\begin{array}{l}\text { Dummy for wage-employment in public } \\
\text { sector }\end{array}$ & & & & 0.34 & 0.12 & & & & \\
\hline Dummy for self-employment in agriculture & & & & & & & 0.17 & 0.51 & \\
\hline Family network characteristics & & & & & & & & & \\
\hline Number of siblings & 2.86 & 4.04 & $* *$ & 3.73 & 3.07 & $* *$ & 3.32 & 3.06 & \\
\hline Resources embedded in the network & & & & & & & & & \\
\hline Siblings' average years of schooling & 4.18 & 4.68 & & 5.05 & 2.07 & $* *$ & 2.87 & 1.62 & $* *$ \\
\hline Dummy for siblings in public sector & 0.10 & 0.20 & & 0.23 & 0.06 & $* *$ & 0.06 & 0.04 & \\
\hline Strenght of ties & & & & & & & & & \\
\hline $\begin{array}{l}\text { Distance from the birthplace to Ouaga } \\
\text { (hours) }\end{array}$ & 2.65 & 3.35 & & 3.58 & 2.36 & $* *$ & 2.71 & 2.45 & \\
\hline Dummy for the whole sibling in Ouaga & 0.20 & 0.17 & & 0.21 & 0.30 & & 0.26 & 0.22 & \\
\hline Dummy for the whole sibling in Burkina but & & & & & & & & & \\
\hline less than half in Ouaga & 0.32 & 0.19 & & 0.30 & 0.34 & & 0.28 & 0.28 & \\
\hline $\begin{array}{l}\text { Dummy for less than half of the siblings in } \\
\text { Burkina }\end{array}$ & 0.09 & 0.14 & & 0.09 & 0.05 & & 0.12 & 0.08 & \\
\hline Dummy for visit to parents & 0.41 & 0.29 & & 0.35 & 0.41 & & 0.30 & 0.37 & \\
\hline Number of individuals & 105 & 112 & & 702 & 162 & & 738 & 113 & \\
\hline
\end{tabular}

Source: Ouaga2009 survey, authors' calculation. Note: in the columns "Sig.", ** means that the difference between "No failure" and "Failure" proportions is significant at the $5 \%$ level.

\section{Some surveys limits}

Note that we do not measure secondary jobs with our survey. In other words, we count the number of workers in different types of occupations and not the number of occupations for the 
workers. Let us clarify the possible consequence of this. If multi-activity were high among workers and if changes in employment status were higher in secondary jobs, then we would most probably underestimate the extent of changes in the considered population. Our numbers of labour market transitions should then be considered as lower bounds of the total number of transitions experienced by workers over their life time. However, from the Phase 1 of the 123 Survey (Phase 1 is a Labour Force Survey) in Ouagadougou in 2002, one can show that less than 9 percent of the employed individuals declared a second activity (Bocquier et al. 2010). Then, we believe that this problem is not too severe. Moreover, using the main activity of the worker is easier to understand and, in a comparative perspective, it fits better with the results of previous studies.

Another important drawback of our data is that we have no way to correctly distinguish formal from informal employment, neither at the firm nor at the worker level. This means that we do not differentiate jobs in the formal and informal sectors. However, some recent studies have shown that using the divide of self-employment, wage-employment and contributing family helpers at the worker level in urban West Africa is still a meaningful way of characterizing the quality and vulnerability of jobs in these cities (Bocquier et al. 2010).

An often mentioned potential issue with survival analysis is the memory problem of the respondents. It relates to whether memory and recall bias on labour market history could affect the results. If recall problems are worse for certain types of workers (unskilled versus skilled, due to longer spells of work of the former; women versus men because women may have more events to recall than men due to their less continuous labour market participation), recall bias may lead the workers to underestimate or overestimate their actual labour market experience in different occupational statuses. The method used to obtain the data should result in minimal recall bias since, rather than asking respondents what they did in any given year, the interviewers asked them to think sequentially through their personal histories. While this technique cannot 
eliminate all potential problems, overall these should be minimized due to the fact that changes in employment status are rare and major events in a person's life and, as such, respondents are likely to recall them with some accuracy. The memory problem in event history surveys should not be overstated as shown by Poulain et al. (1992) in their paper matching biographical survey data and administrative registers at the individual level in Belgium.

\section{Estimation strategy}

\section{The hazard models}

To estimate labour market transitions and changes in employment status, we rely on a survival analysis that makes use of proportional hazards models for discrete-time data. The hazard rate characterizes individuals' propensity to leave a state after a certain spell duration $t$, given that an escape from this state did not occur prior to $t$. Since our event history dataset records year events for each individual since birth, we do not know the exact time of failure in months, but just a year interval in which the failure occurred. Hence, our survival times are interval censored rather than intrinsically discrete. For this reason, we prefer the complementary log-log model, also called the cloglog (see Jenkins 2005 for further details).

The cloglog model is a form of generalized linear model and is appropriate for interval-censored survival data. Complementary log-log models are also frequently used when the probability of an event is very small or very large. One alternative of cloglog models could be the logistic model. The advantage of cloglog model is that it is a discrete-time equivalent of the widely used Cox proportional hazard model. In practice, cloglog and logistic hazard models that share the same duration dependence specification and the same covariates $X$ yield similar estimates as long as the 
hazard rate is relatively "small" (Jenkins 2005). ${ }^{15}$ We tested whether it was indeed the case with our data and found evidence that our results were qualitatively unchanged with logistic regressions.

Let us now detail the regressors $X$ introduced in the hazard regressions. Three vectors of explanatory variables are considered. The first one corresponds to individuals' socio-demographic characteristics that are assumed to be fixed over the survival time considered (called $X_{1}$ ). It then reveals the individuals' situation at the date of the survey. $X_{1}$ includes Ego's age in years in 2009 which allows us to controlling for the cohort effect, a dummy for being Muslim, another for belonging to the majority ethnic group (Moore), Ego's sibling birth-order, which is deemed to affect his schooling, health but also labour market outcomes (Behrman and Taubman 1986; Horton 1988), three dummies for his level of schooling (primary, lower secondary, higher secondary and above), and a standard of living index, which is supposed to partially control for Ego's social background in terms of wealth, because of the very low level of social mobility observed in Burkina Faso (Pasquier-Doumer 2012). This index is calculated using multiple correspondence analysis on the basis of information on the ownership of durable goods, dwelling conditions, and access to utilities. ${ }^{16}$ An additional control is introduced for the transition from self-employment to wage-employment: a dummy indicating whether the worker was employed in the agricultural sector.

\footnotetext{
15 Indeed, one can show that with a sufficiently small hazard rate, the proportional odds model (a linear function of duration dependence and characteristics) is a close approximation to a model with the log of the hazard rate as dependent variable. We also do not rely on the Andersen-Gill model (Andersen et al. 1993) because its main drawback is that it assumes no inter-individuals variations of the probability of failure, and also no dependence over time (through its non-homogenous Poisson process). We believe these assumptions are too strong regarding the risk of transitions which necessarily implies some degree of inter-workers variations and time-dependence.

16 The set of variables is the ownership of TV, radio, refrigerator, fan, bicycle, motorbike, car, computer, the ownership of housing, WC, own kitchen, in-house running water facility, electricity, composition of wall, house keeper, type of housing, street lighting and garbage collection. The index is built using the coordinates of the first axis, which is very discriminating in terms of standard of living.
} 
We also use time-varying covariates $\left(X_{2 j}\right)$ which comprise the individuals' potential experience in the labour market ${ }^{17}$, the time elapsed since the individual arrived in Ouagadougou at the transition time (which is equal to the survival age for non-migrants), the time elapsed since first child birth at the transition time (equal to zero for individuals with no children), and a period dummy taking value one if the transition failure occurred prior to the devaluation of the CFA Francs in 1994. This latter variable is introduced as a control for conjuncture and policy measures effects following the Burkinabe's Structural Adjustment Program, which may have shaped labour market insertion and dynamics.

Finally, we introduce the vector of variables characterizing the individuals' social network at the time of the survey $(S N)$. These variables are described in the data section and discussed using a principal component analysis, which is detailed below. The discrete-time hazard function (cloglog function) that we estimate for interval $\left(a_{j-1}, a_{j}\right]$ can be written as

$$
h\left(j, X_{j}\right)=1-\exp \left[-\exp \left(\beta_{1}^{\prime} X_{1}+\beta_{2}^{\prime} X_{2 j+} \delta^{\prime} S N+\gamma_{j}\right)\right]
$$

In the model considered so far, all differences between individuals were assumed to be captured using observed explanatory variables. We then allow for unobserved individual effects in the models. In the bio-medical sciences which model survival times, they are usually referred to as 'frailty', which corresponds to an unobserved propensity to experience an adverse health event. In the case of labour market transitions, ignoring unobserved heterogeneity may result in different biases (Jenkins 2005): first, non-frailty model may over-estimate the degree of negative duration dependence in the true baseline hazard, and under-estimate the degree of positive duration dependence. In other words, other things being equal, a selection effect may induce individuals with high values of unobserved heterogeneity (or more capable workers) to fail faster

\footnotetext{
${ }^{17}$ This experience variable is not computed from the respondents' age, years of schooling, and age at school entry (as it is usually done), but makes use of the property of the event history data (Nordman and Roubaud 2009): we do observe the actual age at the labour market entry and so can just deduct it from the age at the date of the survey. This provides us with a 'quasi-potential' experience variable.
} 
(i.e. to exit from unemployment or to obtain better jobs faster). In such case, the survivors at any given survival time are increasingly composed of observations with relatively low values of unobserved heterogeneity (discouraged or unmotivated workers) and then lower hazard rates. Second, the proportionate effect of a given regressor on the hazard rate $(\beta)$ is no longer constant and independent of survival time. Third, the presence of unobserved heterogeneity may yield an underestimation of any positive $\beta$ derived from an uncorrected model, and reciprocally an overestimation of any negative effect (Lancaster 1990).

With $u$ denoting a random variable with a mean of zero and finite variance, the model specification for a frailty hazard rate may simply be written as

$$
h\left(j, X_{j}\right)=1-\exp \left[-\exp \left(\beta_{1}^{\prime} X_{1}+\beta_{2}^{\prime} X_{2 j+} \delta^{\prime} S N+\gamma_{j}+u\right)\right]
$$

The random variable $u$ may be interpreted in several ways. The most common interpretation is that it summarises the impact of omitted variables on the hazard rate. Alternative readings are usually measurement errors in the recorded regressors or recorded survival times. To estimate this model, we require expressions for density and survival functions that do not condition on the unobserved effects. This is generally called 'integrating out' the unobserved effect. For the discrete-time proportional hazard model $(\log \log )$, the Gamma distribution has been one of the most popular distributions. This is the approach we follow by using a maximum likelihood estimation of the proportional hazard models incorporating a Gamma mixture distribution to summarize unobserved individual heterogeneity.

\section{Analysis of family networks using a principal component analysis}

Following Dickerson and Green (2004), Jellal et al. (2008) or Fernandez and Nordman (2009) in other contexts, we use a principal component analysis (PCA) to summarize the observed information about the men's family network in order to circumvent the potential multicollinearity 
of family network variables. In principal component analysis ${ }^{18}$, a set of variables is transformed into orthogonal components, which are linear combinations of the variables and have maximum variance subject to being uncorrelated with one another. Typically, the first few components account for a large proportion of the total variance of the original variables, and hence can be used to summarize the original data. The computed factors were rotated using an oblique rotation to ease their interpretation. If one can provide a qualitative interpretation of each of the PCA axes as we do, the generated PCA axes can be used as substitutes for social network variables in the labour market changes regressions.

Table A1 in Appendix reports the main diagnostics of this PCA. ${ }^{19}$ For our purpose, the first six axes are retained, as they concentrate most of the total variance of the original variables (93 percent) and reflect, therefore, a fair amount of the relevant information about the individuals' family network characteristics. The pairwise correlation coefficients of the family network's and individual's main characteristics with the first six factors are then used for the interpretation of the computed factors (Table A2 in Appendix).

The six factors are closely associated with the following characteristics: Factor 1 corresponds to the resources related to social capital embedded in the networks, combining education and, to a lesser extent, the activity portfolio of the network (whether its members have a job in the public sector). Factor 2 is mainly summarized by the distance to the region or village of origin, as it is highly correlated to the two variables describing the costs (in CFA francs) and time (in hours) necessary to travel to the individual's locality of origin. This factor may be interpreted as the weakness of ties with the kinship as a whole. Factor 3 is highly correlated to information summarizing the fragmentation of the siblings, i.e. whether siblings live in Ouagadougou and abroad. Its interpretation is very close to that of Factor 2, but with a restricted definition of

\footnotetext{
${ }^{18}$ We have tried other techniques of factor analysis, such as the principal factor method, which leads to similar results.

${ }^{19}$ Further details on this PCA can be obtained from the authors upon request.
} 
kinship, i.e. the weakness of ties with the biological family. Factor 4 reflects the sibling network size. Factor 5, like Factor 1, reflects the resources embedded in the family network but gives a higher weight to the resources related to labour market outcomes. Finally, Factor 6 stresses strong ties with the extended family, as it is positively correlated with the number of visits to parents. More precisely, it reflects the reciprocity dimension of the strong ties as paying a visit may measure the effort provided to foster links with the family.

These six factors therefore reflect a wide range of social network characteristics. More importantly, we find that the factors are rather clearly defined and have all a relevant interpretation according to the literature. These network characteristics can mainly be described by the network's size/structure, network's resources (education, professional activity of its members), and strength of ties (geographical remoteness, fragmentation and reciprocity). ${ }^{20}$

\section{Results}

Table 3 reports the results of the hazard model estimations for family network variables (full results are presented in Table A3 in Appendix). For each transition, Models 1 and 2 estimate hazard rates without controlling for the time-invariant unobserved heterogeneity of individuals (non-frailty models). In addition, Models 3 and 4 report the frailty estimates. Family networks are approximated by the most influential family network variables in Models 1 and 3, and by the computed Factors resulting from the PCA in Models 2 and 4 (see previous section).

\footnotetext{
${ }^{20}$ As a robustness check, we split the sample randomly into two halves and performed the PCA on each half. The results remain unchanged.
} 
Table 3. Hazard regressions results

\begin{tabular}{|c|c|c|c|c|c|c|c|c|c|c|c|c|}
\hline \multirow[b]{2}{*}{ Family network variables } & \multicolumn{4}{|c|}{ Unemployment to Employment } & \multicolumn{4}{|c|}{ Wage Employment to Self-Employment } & \multicolumn{4}{|c|}{ Self-Employment to Wage Employment } \\
\hline & $\begin{array}{c}\text { (1) } \\
\text { Non- } \\
\text { frailty } \\
\text { model }\end{array}$ & $\begin{array}{c}\text { (2) } \\
\text { Non- } \\
\text { frailty } \\
\text { model }\end{array}$ & $\begin{array}{c}(3) \\
\text { Frailty } \\
\text { model }\end{array}$ & $\begin{array}{c}\text { (4) } \\
\text { Frailty } \\
\text { model }\end{array}$ & $\begin{array}{c}\text { (1) } \\
\text { Non- } \\
\text { frailty } \\
\text { model }\end{array}$ & $\begin{array}{c}\text { (2) } \\
\text { Non- } \\
\text { frailty } \\
\text { model }\end{array}$ & $\begin{array}{c}(3) \\
\text { Frailty } \\
\text { model }\end{array}$ & $\begin{array}{c}\text { (4) } \\
\text { Frailty } \\
\text { model }\end{array}$ & $\begin{array}{c}\text { (1) } \\
\text { Non- } \\
\text { frailty } \\
\text { model }\end{array}$ & $\begin{array}{c}(2) \\
\text { Non- } \\
\text { frailty } \\
\text { model }\end{array}$ & $\begin{array}{c}(3) \\
\text { Frailty } \\
\text { model }\end{array}$ & $\begin{array}{c}(4) \\
\text { Frailty } \\
\text { model }\end{array}$ \\
\hline Siblings size & $\begin{array}{l}-0.0471 \\
(0.0623)\end{array}$ & & $\begin{array}{l}-0.0244 \\
(0.0646)\end{array}$ & & $\begin{array}{l}-0.00574 \\
(0.0559)\end{array}$ & & $\begin{array}{l}-0.0514 \\
(0.0566)\end{array}$ & & $\begin{array}{l}-0.00213 \\
(0.0656)\end{array}$ & & $\begin{array}{c}0.0102 \\
(0.0688)\end{array}$ & \\
\hline Siblings' average years of schooling & $\begin{array}{l}-0.0498^{*} \\
(0.0313)\end{array}$ & & $\begin{array}{l}-0.0397 \\
(0.0332)\end{array}$ & & $\begin{array}{l}0.00101 \\
(0.0289)\end{array}$ & & $\begin{array}{l}0.00566 \\
(0.0299)\end{array}$ & & $\begin{array}{l}-0.0694^{*} \\
(0.0419)\end{array}$ & & $\begin{array}{l}-0.113 * * \\
(0.0488)\end{array}$ & \\
\hline Siblings in public sector & $\begin{array}{l}0.279 \\
(0.337)\end{array}$ & & $\begin{array}{l}0.399 \\
(0.342)\end{array}$ & & $\begin{array}{l}-0.216 \\
(0.331)\end{array}$ & & $\begin{array}{l}-0.476 \\
(0.374)\end{array}$ & & $\begin{array}{l}0.459 \\
(0.431)\end{array}$ & & $\begin{array}{l}0.664 \\
(0.465)\end{array}$ & \\
\hline $\begin{array}{l}\text { Distance from the birth place } \\
\text { to Ouaga (hours) }\end{array}$ & $\begin{array}{l}0.0951^{*} \\
(0.0550)\end{array}$ & & $\begin{array}{c}0.0901 * * \\
(0.0422)\end{array}$ & & $\begin{array}{c}0.0239 \\
(0.0514)\end{array}$ & & $\begin{array}{c}0.0230 \\
(0.0496)\end{array}$ & & $\begin{array}{c}0.0297 \\
(0.0579)\end{array}$ & & $\begin{array}{l}-0.0181 \\
(0.0601)\end{array}$ & \\
\hline Siblings' remoteness to Ouaga & $\begin{array}{l}0.137^{*} \\
(0.0743)\end{array}$ & & $\begin{array}{l}0.117^{* *} \\
(0.0571)\end{array}$ & & $\begin{array}{l}-0.0600 \\
(0.0759)\end{array}$ & & $\begin{array}{l}-0.0655 \\
(0.0674)\end{array}$ & & $\begin{array}{c}0.0944 \\
(0.0791)\end{array}$ & & $\begin{array}{c}0.131^{*} \\
(0.0813)\end{array}$ & \\
\hline Visit to parents & $\begin{array}{l}-0.112 \\
(0.229)\end{array}$ & & $\begin{array}{l}-0.0918 \\
(0.222)\end{array}$ & & $\begin{array}{c}0.106 \\
(0.189)\end{array}$ & & $\begin{array}{c}0.226 \\
(0.201)\end{array}$ & & $\begin{array}{l}-0.0429 \\
(0.234)\end{array}$ & & $\begin{array}{l}-0.218 \\
(0.263)\end{array}$ & \\
\hline $\begin{array}{l}\text { Factor } 1 \text { (Resources in human capital } \\
\text { embedded in the network) }\end{array}$ & & $\begin{array}{l}-0.246^{*} \\
(0.146)\end{array}$ & & $\begin{array}{l}-0.192 \\
(0.148)\end{array}$ & & $\begin{array}{l}0.0391 \\
(0.132)\end{array}$ & & $\begin{array}{l}0.0159 \\
(0.138)\end{array}$ & & $\begin{array}{l}-0.281^{*} \\
(0.185)\end{array}$ & & $\begin{array}{c}-0.447 * * \\
(0.200)\end{array}$ \\
\hline $\begin{array}{l}\text { Factor } 2 \\
\text { (Distance to the origin locality/Weak ties with } \\
\text { kinship) }\end{array}$ & & $\begin{array}{l}0.233^{*} \\
(0.137)\end{array}$ & & $\begin{array}{l}0.216^{*} \\
(0.131)\end{array}$ & & $\begin{array}{l}0.0435 \\
(0.126)\end{array}$ & & $\begin{array}{l}0.0573 \\
(0.174)\end{array}$ & & $\begin{array}{l}0.0528 \\
(0.143)\end{array}$ & & $\begin{array}{l}-0.0433 \\
(0.157)\end{array}$ \\
\hline $\begin{array}{l}\text { Factor } 3 \text { (Fragmentation of the siblings / Weak } \\
\text { ties with siblings) }\end{array}$ & & $\begin{array}{l}0.195^{*} \\
(0.107)\end{array}$ & & $\begin{array}{l}0.172 * \\
(0.105)\end{array}$ & & $\begin{array}{l}-0.0855 \\
(0.124)\end{array}$ & & $\begin{array}{l}-0.189 \\
(0.141)\end{array}$ & & $\begin{array}{l}0.186^{*} \\
(0.126)\end{array}$ & & $\begin{array}{l}0.255^{*} \\
(0.132)\end{array}$ \\
\hline Factor 4 (Size of the sibling network) & & $\begin{array}{l}-0.156 \\
(0.131)\end{array}$ & & $\begin{array}{l}-0.104 \\
(0.127)\end{array}$ & & $\begin{array}{l}0.0254 \\
(0.114)\end{array}$ & & $\begin{array}{l}-0.0739 \\
(0.127)\end{array}$ & & $\begin{array}{l}0.0946 \\
(0.141)\end{array}$ & & $\begin{array}{c}0.140 \\
(0.145)\end{array}$ \\
\hline $\begin{array}{l}\text { Factor } 5 \text { (Occupational resources embedded } \\
\text { in the network) }\end{array}$ & & $\begin{array}{c}0.134 \\
(0.108)\end{array}$ & & $\begin{array}{l}0.172^{*} \\
(0.105)\end{array}$ & & $\begin{array}{l}-0.105 \\
(0.111)\end{array}$ & & $\begin{array}{l}-0.161 \\
(0.121)\end{array}$ & & $\begin{array}{l}0.0882 \\
(0.146)\end{array}$ & & $\begin{array}{c}0.135 \\
(0.155)\end{array}$ \\
\hline Factor 6 (Reciprocity/ Strong ties with kinship) & & $\begin{array}{l}-0.0258 \\
(0.107)\end{array}$ & & $\begin{array}{r}-0.0226 \\
(0.108)\end{array}$ & & $\begin{array}{c}0.0480 \\
(0.0879)\end{array}$ & & $\begin{array}{c}0.106 \\
(0.0933)\end{array}$ & & $\begin{array}{l}-0.0246 \\
(0.109)\end{array}$ & & $\begin{array}{l}-0.107 \\
(0.124)\end{array}$ \\
\hline $\begin{array}{l}\text { Other controls } \\
\text { (see Appendix, Table A3) }\end{array}$ & Yes & Yes & Yes & Yes & Yes & Yes & Yes & Yes & Yes & Yes & Yes & Yes \\
\hline Constant & $\begin{array}{c}-4.043^{* * *} \\
(0.781)\end{array}$ & $\begin{array}{c}-3.737 * * * \\
(0.703)\end{array}$ & $\begin{array}{c}-4.025^{* * *} \\
(0.329)\end{array}$ & $\begin{array}{c}-3.662^{* * *} \\
(0.356)\end{array}$ & $\begin{array}{c}-4.729 * * * \\
(0.753)\end{array}$ & $\begin{array}{c}-4.868^{* * *} \\
(0.637)\end{array}$ & $\begin{array}{c}-4.749 * * * \\
(0.518)\end{array}$ & $\begin{array}{c}-5.061 * * * \\
(0.312)\end{array}$ & $\begin{array}{c}-5.513^{* * *} \\
(0.910)\end{array}$ & $\begin{array}{c}-5.353^{* * *} \\
(0.758)\end{array}$ & $\begin{array}{c}-5.245^{* * *} \\
(0.492)\end{array}$ & $\begin{array}{c}-5.311 * * * \\
(0.518)\end{array}$ \\
\hline Observations & 1324 & 1324 & 1324 & 1324 & 10544 & 10544 & 10544 & 10544 & 10726 & 10726 & 10726 & 10726 \\
\hline
\end{tabular}

Source: Ouaga2009 survey, authors' calculation. Note: Standard errors in parentheses, ${ }^{* * *} \mathrm{p}<0.01, * * \mathrm{p}<0.05, * \mathrm{p}<0.10$. 


\section{Transition from unemployment to employment}

Looking at the non-frailty Model 1, three characteristics of the network seem to influence (at the 10 percent level) the propensity to find a job when individuals are unemployed: the average education of the siblings, with a negative effect; the distance to the area of origin, with a positive sign; and the siblings' remoteness to Ouagadougou, again with a positive sign. By taking into account the individuals' unobserved heterogeneity in Model 3, we refine these estimates, and the effect of the siblings' education vanishes, while the other two significant effects are reinforced (at the 5 percent level).

The two remaining significant and robust effects of geographical location (distance to origin locality and remoteness of the siblings) have an interesting interpretation in this context of access to employment. They suggest that a longer distance between the unemployed and his/her kin in the village of origin leads to quicker access to employment. This may happen for a least two reasons. First, the longer the distance to the family who stays in the locality of origin, the less efficient the safety net in case of unemployment. Thus, migrants to the capital who find themselves far from their origin locality might be even more motivated to find a job, and may accept job offers faster than migrants who left a closer locality where it is easier to find support from their family in case of financial difficulties. Rasmanês life history (Interview 6) highlights the difficulty to survive far from his family. When Rasmané, a tailor of 45 years old, migrated to Ouagadougou, he was 14 years old and did not know anybody in Ouagadougou except a distant friend of his father, with whom the father made business of kola nuts. His parents sent him to Ouagadougou with the hope that he will learn a trade. Unlike the other children of the father's friend, he was undernourished and had to work hard to contribute to the expenses of the household. This leads him to say: "In Africa, when you do not have your family nearby, you should know that you will suffer". Balkissa (Interview 1), a 41 years old unemployed widow, also illustrates the difficulty to live far from her family. She had to leave the family neighbourhood in Ouagadougou 
when her husband died to join a cheaper and suburban district. The head of her family, her father's brother, gives her some help, but only when she visits him. Because she is poor, it is very difficult for her to cross the city to visit them.

A second interpretation calls for the possible disincentive effect exerted by the family network in terms of 'earnings predation'. Such adverse incentive effects could arise if migrants feel that everything they earn needs to be shared with the close and extended family, or that labour incomes may even attract family members with whom these earnings have to be shared. ${ }^{21}$ Demands from the kin or more broadly from people in the village of origin may then have a disincentive effect on the job search and this effect gets diluted with geographical distance. Indeed, the longer the distance to the kinship network, the higher the costs for the kin to observe the labour earnings of the worker. As an illustration, Francois, together with his wife Denise (Interview 2), both self-employed as tiler and weaver respectively, explains that he keeps close ties with his family that lives in a village 15 kilometers away from Ouagadougou. They both pay regular visits to the parents of François, and they also receive regular visits from sisters and brothers at various occasions. They receive presents from the village, but they both have the feeling that they "give more than they receive". This is because the members of the family of Francois are worse off than they are. In the same vein, Inoussa (Interview 13), 29 years old, an apprentice in a store of furnitures, has migrated to Ouagadougou when he was 18 years old, from a village 18 kilometers away, where his family still resides. He explains that he has many friends from the village who come to Ouagadougou and visit him. They are often hosted by Inoussa for several days. As he says, "In Africa, if you know somebody and you don't know his place, it is as if you actually don't know bim".

21 The idea that family and kinship ties may imply adverse incentive effects is relatively old. It is quite often mentioned in the anthropological literature, was emphasized by modernization theorists, and was developed in the field of economic sociology and social network analysis as the downside of strong ties. More recently, this question has been taken up by economists (see e.g. Platteau 2000; Hoff and Sen 2006; Luke and Munshi 2006; Grimm et al. 2013). 
We then refine these estimates by looking at the other set of regressions which replace the family network characteristics introduced in levels by the six computed factors stemming from the principal component analysis (Models 2 and 4, non-frailty and frailty respectively). As mentioned in Section 3, this procedure has the advantage of introducing regressors which are, by definition, orthogonal to each other, therefore circumventing potential multicollinearity issues among social network variables. In addition, in so doing, we intend to test the effect of combined dimensions of the individuals' family, providing therefore a complement to previous estimates. Finally, as shown before, the six factors have a rather clear interpretation which may clarify the meaning of our econometric results.

From our (preferred) frailty Model 4, we find that Factor 2 and Factor 3 exert a positive and significant effect on the probability of escaping from unemployment. We thus confirm the previous positive effect of the fragmentation of the siblings (Factor 3) and of the distance to the origin locality (Factor 2). The novelty here comes from the effect of Factor 5, which reflects the resources of the siblings in terms of activity portfolio (having siblings in the public sector). Workers with such resources obtained a job faster. This may illustrate cases where unemployment is a waiting room for jobs in the public sector, a situation where having a family member in this sector helps get access to this labour market segment.

Thus, on the one hand, we find that the proximity with kinship network does not necessarily help the unemployed find a job in the context of Ouagadougou. On the contrary, it may exert a disincentive effect, through the provision of a safety net or a pressure to redistribute, that leads unemployed to limit their effort to seek for a job. This result is very different from what is generally observed in developed countries (Bentolila et al. 2010). This may be due to different meanings of being unemployed in the African context, where underemployment more accurately summarizes different forms of distortion on the labour market and where there is no unemployment insurance. On the other hand, the presence of a relatively highly rewarding public 
sector compared to other labour market segments (Kuepie et al. 2009) still seems to favour a situation where unemployed workers have incentives to queue for jobs in this sector, especially when the resource embedded in their family network (i.e. public sector siblings) is favorable.

\section{Transition from wage employment to self-employment}

As shown in Table 3, family network variables have no clear and significant effects on the propensity to experience a transition from wage employment to self-employment. This is especially true when non-frailty models are considered (Models 1 and 2). This diagnosis changes slightly if we control for unobserved individual effects (Models 3 and 4), but the overall significance of the coefficients remains poor and beyond the reach of the 10 percent level threshold. Besides, as frailty models mitigate time-invariant unobserved heterogeneity bias, we limit the discussion to these models, and just discuss the signs of the coefficients. Three variables deserve attention in these specifications, as their coefficients almost reach the 15 percent confidence threshold: the siblings' remoteness to Ouagadougou (Model 3), the fragmentation of the siblings (Factor 3) and the occupational resources embedded in the network (Factor 5).

The fragmentation of the siblings (siblings' remoteness to Ouagadougou, and Factor 3), which may approximate the weakness of ties with the siblings, has a negative effect: for wage workers, having weak ties with the siblings may decrease the propensity to become self-employed. It is especially true when wage workers get older. ${ }^{22}$ Francois' transition (Interview 2) illustrates this result. When he dropped out of school, François worked as unpaid worker in the family farm for eight years. He decided to migrate to Ouagadougou to join his siblings and found a job as domestic. When he lost this job six months later, his brother gave him 10000 FCFA to buy a 'board' and to become street vendor. Denise, his wife, experienced a similar transition: after losing her job as hairdresser, she became self-employed weaver thanks to a familial informal loan of

\footnotetext{
22 When we estimate Models 3 and 4 with interactions between age and family network variables (not reported here to save space), we find a significant (at the 1 percent confidence threshold) and negative coefficient of the interaction term between Factor 3 and age.
} 
22500 FCFA, which allowed her to buy a loom. As already mentioned, Denise and François keep up very close ties with their family through frequent visits and gifts since they arrived in Ouagadougou.

In addition, Factor 5, reflecting the resources potentially useful to be successful on the labour market (siblings in the public sector), has a negative coefficient, meaning that this resource may be discouraging to experience such a transition. Then, family networks with high level of resources may encourage wage-earners to remain in their status. The high value and negative sign of the coefficient on the dummy indicating siblings in the public sector in Model (3) calls for the same interpretation, although its point estimate is quite imprecise ( 20 percent confidence level).

Finally, these regressions elicit the hazardous and precarious nature of self-employment, as having children ${ }^{23}$ or having of high level of education convey negative and significant effects on the transition to self-employment (see Table A3 in Appendix).

Thus, family network does not play a significant role in experiencing transition from wage employment to self-employment. One of the reasons might be the low initial investment required to become self-employed in West African labour markets, as shown in Grimm, Krüger, and Lay (2011) for informal activities. However, our results suggest than strong family ties may facilitate the transition from wage- to self-employment, although the effect we observe are not so robust. Proximity with the siblings could provide a supportive network which may help cope with the risks associated with the self-employment status. On the contrary, having occupational resources embedded in the family network seems to encourage workers to remain wage employed. But again, the effect is weak on average, while it becomes robust for older wage workers.

\footnotetext{
${ }^{23}$ More precisely, we measure the effect of the time elapsed since the birth of the first child. The longer this time spell, the higher the probability to have other children.
} 
We note two robust effects of family networks on the propensity to experience a transition from self-employment to wage employment (Table 3): the weakness of sibling ties (Factor 3 in Model 4, or siblings' remoteness to Ouagadougou in Model 3) has a positive effect; on the contrary, the resources in human capital of this network (Factor 1 in Model 4 or average education level of the siblings in Model 3) have a negative and significant effect on this propensity (at the 5 percent level in the frailty specification). Consequently, a high level of resources in human capital embedded in the network is associated with a longer duration in self-employment. This may mean that the opportunity cost for individuals with high level of resources in human capital to transit from self-employment to wage-employment is higher compared to workers who have a lower level of these resources. Indeed, having sibling with higher level of education may help access credits and/or information about market opportunities.

Looking at the coefficients on other individual characteristics in Table A3 in Appendix, it appears that recent migrants, in particular those who were farmers previously, are more concerned with this transition, since being self-employed in the agricultural sector and the time elapsed since the individual arrived in Ouagadougou have both a significant effect, in particular in the frailty specification (3), positive in the first case, negative in the second. More educated workers have a higher propensity to transit from self-employment to wage employment probably because of selection into migration, as illustrated by the work history of Boukaré (Interview 9), a building custodian of 34 years old, who was a self-employed farmer and was selected by his family to migrate to Ouagadougou because he was the most educated of the family.

This result suggests that workers without strong sibling ties are encouraged to make more effort to socialize as they may not find continuous support from their siblings. For instance, Frederick (Interview 5), a 29 years old man resuming his studies at the time of the survey, whose older brother lives in another city (Koudougou), spends a lot of time in his 'grin', an informal 
association of individuals of the same generation, living generally in the same neighborhood, and who meet up each other in the street to drink tea, chat and play cards. Kieffer (2006) defines the 'grin' in Ouagadougou as a place where individuals are engaged in reciprocal relationships, especially with the "big brothers" who play a protective role, are solicited for occupational projects, offer job opportunities and receive services in exchange. This 'grin' is for Frederick an essential source of information, which allows him to obtain various professional contacts and jobs opportunities. Through his 'grin', he found a wage employment as enumerator for an international NGO. He also developed a network of truck rental companies and he met a logistician to discuss the opportunity of this career path that he aims for.

These results seem to confirm Granovetter's predictions on the strength of the weak ties: weak ties allow self-employed workers to get a better access to information on wage employment opportunities. Introducing resources dimension, however, changes the perception of the role of family network in the transition from self-employment to wage employment. Indeed, kinship networks endowed with high educational resources seem to discourage self-employed workers to become wage workers. Knowing that wage jobs obtained through the family network after a selfemployed job may be of poor quality, as discussed by the descriptive analysis (Table 2) and confirmed by our qualitative interviews, we may conclude that weak ties then enhance access to information on jobs but that this information is of little value.

By contrast, having a good quality network may encourage workers to evolve as self-employed. Indeed, in some cities and activities of West Africa, it is not uncommon to find unregistered selfemployed workers, therefore belonging to the informal sector, following some of the management rules of modern enterprises. A few authors have thus identified an 'upper segment' of the informal sector, which would be less vulnerable in terms of earnings than the bulk of wage-employment situations (see Fields 2004; Bocquier et al. 2010). Analysis of the qualitative interviews also illustrates the role of the resources of family network and the strength of non- 
kinship ties to experience upward mobility inside self-employment status. Awa (Interview 10), a 37 years old highly educated woman born in Bamako (Mali), who has migrated following her husband, explains the success of her textile trade by the help of friends and those of her husband to create a clientele, but also to invest in her activity. According to her, "friends are more able to understand money issues", supposedly than the family.

Crossed effects of the family variables with age complement and somehow confirm these findings: strong ties with the extended family measured by the number of visits paid to parents (Factor 6 ) exert a negative and significant effect (at the 10 percent level) on transition from self- to wage employment, but this negative effect diminishes slightly with workers' age. This refinement reinforces the finding that strong family ties play a stabilizing role in labour market dynamics: having frequent interactions with the family increases the probability to remain in the same status of activity for self-employed workers.

\section{Conclusion}

The aim of this paper is to shed light on the role of family networks in the dynamics of workers on the labour market of a West African country. The main issue tackled is the extent to which one's network is essential in labour market transitions, in particular from unemployment to employment, from wage employment to self-employment, or from self-employment to wage employment. In addition, this paper investigates which dimension of the family network has the main effect on these transitions, by distinguishing the resources embedded in the network from its structure and the strength of the ties. For this purpose, we use an original survey conducted in 2009 in Ouagadougou on a representative sample of 2000 households. This survey provides event history data and very detailed information on the workers' social networks. In addition, we conducted qualitative interviews of a sub-sample of the workers having responded to the event 
history questionnaire. To estimate labour market transitions and changes in the workers' employment status, we rely on a survival analysis that makes use of proportional hazard models for discrete-time data.

We find that family networks have a significant effect on the transitions of individuals on the labour market, even if this effect is less robust for the transition from wage- to self-employment. In addition, the results differ depending on the type of transition and on the dimension of the family network considered, i.e. the sibling network size, the resources available in the network, and the strength of ties.

The family network size, approached by the sibling size, appears to not matter much in the labour market dynamics. Size is far from being the most important dimension of family networks in the transition from unemployment to employment. This is an important finding with regard to the existing literature, which mostly focuses on developed countries and highlights the efficient role of network size in job search. One of the reasons why this contradiction may exist is that the safety net function of the family network could dominate its informative function in a context where there is no formal safety net scheme for unemployed workers.

Regarding the strength of ties, strong ties seem to play a stabilizing role in labour market dynamics. Indeed, having a network endowed in strong ties, in particular strong family ties, increases the probability to remain in the same status of activity for self-employed and unemployed workers. Strong ties seem to be of little use for access to wage employment, except to access to public sector. During the job search, unemployed workers having strong ties in their family networks may tend to limit their effort to find a job. These results reinforce the idea that the safety net function of strong ties dominates their informative function. Strong ties facilitate transitions in only one case, the transition from wage employment to self-employment, but this effect is not robust. Strong ties may help self-employed workers face uncertainty or invest in a 
small business, but as they go hand in hand with homophily, they do not seem to help get away from a precarious status in the labour market.

In the same way, resources embedded in the network are a factor of occupational immobility: they have a negative effect on occupational transitions and this effect is reinforced when resources are combined with strong ties. The greater the network resources, the weaker the incentive to find a job, and the more profitable it is to evolve within the self-employment or within wage employment, albeit in a lesser extent.

Finally, what this study actually points out is that family networks, and more broadly social networks, have to be addressed taking into account their three explored dimensions. If not, the effect of social networks on labour market dynamics and labour market outcomes may well be misunderstood, in particular if network size is solely considered. This paper advocates the development of theoretical approaches that would take into account the coexistence of both the informative and safety net functions of social networks, which is particularly essential in a developing country context. Another fruitful research agenda would be to deepen the understanding of social networks as factors of social immobility. However, data scarcity on the formation and development of social networks in developing countries is a concern as, ideally, what one would like to observe is the dynamics of personal networks across generations. 


\section{References}

Andersen, P. K., O. Borgan, R. D. Gill, and N. Keiding. 1993. Statistical Models Based on Counting Processes, Springer-Verlag, New York.

Barr, Abigail M. 2002. "The Functional Diversity and Spillover Effects of Social Capital.” Journal of African Economies 11 (1):90-113.

Bentolila, Samuel, Claudio Michelacci, and Javier Suarez. 2010. "Social Contacts and Occupational Choice." Economica 77: 20-45.

Behrman, Jere R., and Paul Taubman. 1986. "Birth Order, Schooling, and Earnings." Journal of Labor Economics 4(3):121-50.

Berrou, Jean-Philippe, and François Combarnous. 2012. "The Personal Networks of Entrepreneurs in an Informal African Urban Economy: Does the 'Strength of Ties' Matter?." Review of Social Economy 70(1):1-30.

Bocquier, Philippe, Christophe J. Nordman, and Aude Vescovo. 2010. "Employment Vulnerability and Earnings in Urban West Africa." World Development 38(9):1297-1314.

Boyer, Florence, and Daniel Delaunay. 2009. “Ouaga 2009, Peuplement de Ouagadougou et Développement urbain." Unpublished manuscript, Institut de Recherche pour le Développement.

Bramoullé, Yann, and Gilles Saint-Paul. 2010. "Social Networks and Labor Market Transitions." Labour Economics 17:188-195.

Calvó-Armengol, Antoni, and Matthew O. Jackson. 2004. "The Effect of Social Networks on Employment and Inequality." American Economic Review 94(3):426-454.

Calvó-Armengol, Antoni, and Matthew O. Jackson. 2007. "Networks in Labor Markets: Wage and Employment Dynamics and Inequality." Journal of Economic Theory 132:27-46.

Carrasco, Raquel. 1999. "Transitions to and From Self-employment in Spain: An Empirical Analysis." Oxford Bulletin of Economics and Statistics 61(3):315-341.

DIAL. 2007. "Youth and Labour Markets in Africa: A Critical Review of Literature." Working paper, DIAL DT 2007/02.

Dickerson, Andrew, and Francis Green. 2004. "The Growth and Valuation of Computing and Other Generic Skills." Oxford Economic Papers 56(3):371-406.

Durlauf, Steven N., and Marcel Fafchamps. 2005. "Social Capital." In : Handbook of Economic Growth, ed. Aghion Philippe. and Steven N. Durlauf. ed1, vol 1(26):1639-1699.

Fafchamps, Marcel. 2002. "Returns to Social Network Capital Among Traders." Oxford Economic Papers 54(2):173-206.

Fernandez, Rosa M., and Christophe J. Nordman. 2009. “Are There Pecuniary Compensations for Working Conditions?” Labour Economics 16(2):194-207.

Fields, Gary. S. 2004. "A Guide to Multisector Labor Market Models.” Paper presented at the World Bank Labor Market Conference, Washington, DC November 18-19.

Granovetter, Mark S. 1973. “The Strength of Weak Ties.” American Journal of Sociology78:1360-80.

Granovetter, Mark S. 1995. Getting a Job: A Study of Contacts and Careers, 2nd ed. Chicago: Chicago University Press. 
Grimm, Michael, Jens Krüger, and Jann Lay. 2011. "Barriers to entry and returns to capital in informal activities: evidence from Sub-Saharan African." Review of Income and Wealth 57: S27S53.

Grimm, Michael, Flore Gubert, Ousmane Koriko, Jann Lay, and Christophe J. Nordman. 2013. "Kinship-ties and Entrepreneurship in Western Africa." Journal of Small Business and Entrepreneurship 26: 125-150.

Gubert, Flore, and Marcel Fafchamps. 2007. “The Formation of Risk Sharing Networks.” Journal of Development Economics 83(2):326-350.

Hoang, Ha, and Bostjan Antoncic. 2003. "Network-based Research in Entrepreneurship: A Critical Review." Journal of Business Venturing 18(2):165-187.

Hoff, Karla, and Amartya Sen. 2006. “The Kin as a Poverty Trap.” In Poverty Traps, ed. Samuel Bowles, Steven N. Durlauf, and Karla Hoff. New York: Princeton University Press.

Horton, Sue. 1988. "Birth Order and Child Nutritional Status: Evidence from the Philippines." Economic Development and Cultural Change 36(2):341-354.

Ioannides, Yannis .M., Linda D. Loury. 2004. "Job Information Networks, Neighborhood Effects, and Inequality." Journal of Economic Literature 42(4):1056-1093.

Jackson, M. 2008. Social and Economic Networks. Princeton: Princeton University Press.

Jellal, Mohamed, Christophe J. Nordman, and François-Charles Wolff. 2008. "Evidence on the Glass Ceiling Effect in France Using Matched Worker-Firm Data." Applied Economics 40(24):3233-3250.

Jenkins, Stephen P. 2005. Survival Analysis, Unpublished manuscript, Institute for Social and Economic Research, University of Essex, Colchester, UK.

Kambourov, Gueorgui, and Iourii Manovskii. 2008. "Rising Occupational and Industry Mobility in the United States: 1968-97." International Economic Review 49(1):41-79.

Kanbur, Ravi. 2005. Q-Squared - Qualitative and Quantitative Methods of Poverty Appraisal, Delhi: Permanent Black.

Kieffer, Julien. 2006. "Les jeunes des " grins » de thé et la campagne électorale à Ouagadougou." Politique Africaine 101:63-82.

Kramarz, Francis, and Oskar Nordstrom Skans. 2013. "When Strong Ties are Strong: Networks and Youth Labor Market Entry", CEPR Discussion Paper No. DP9620.

Kuépié, Mathias, Nordman, Christophe J., and François Roubaud. 2009. "Education and Earnings in Urban West Africa." Journal of Comparative Economics 37(3):491-515.

La Ferrara, Eliana. 2007. Family and Kinship Ties in Development: An Economist's Perspective. Paper presented at the 5th AFD-EUDN Conference, Paris, December.

Lancaster, Tony. 1990. The Econometric Analysis of Transition Data, Cambridge: Cambridge University Press.

Lin, Nan. 1990. "Social Resources and Social Mobility: A Structural Theory of Status Attainment." In Social Mobility and Social Structure, ed. Breiger R.L. New York: Cambridge University Press.

Lourenço-Lindell, Ilda. 2002. Walking the Tight Rope: Informal Livelihoods and Social Networks in a West African City, Stockholm: Stockholm Studies in Human Geography 9, Almquist and Wiksell International. 
Magruder, Jeremy R. 2010. "Intergenerational Networks, Unemployment, and Persistent Inequality in South Africa." American Economic Journal: Applied Economics 2(1):62-85.

Meagher, Kate. 2006. "Social Capital, Social Liabilities, and Political Capital: Social Networks and Informal Manufacturing in Nigeria." African Affairs 105(421):553-582.

McCallister, Lynne, and Claude Fischer. 1978. "A Procedure for Surveying Personal Networks." Sociological Methods and Research 7:131-148.

McKeever, Matthew. 2006. "Fall Back or Spring Forward? Labor Market Transitions and the Informal Economy in South Africa." Research in Social Stratification and Mobility 24:73-87.

McPherson, Miller, Lynn Smith-Lovin, and James M. Cook. 2001. "Birds of a Feather: Homophily in Social Networks." Annual Review of Sociology 27:415-44.

Nordman, Christophe J., and François Roubaud. 2009. "Reassessing the Gender Wage Gap in Madagascar: Does Labor Force Attachment Really Matter?" Economic Development and Cultural Change 57(4):785-808.

Pasquier-Doumer, Laure. 2010. "Le rôle du réseau social dans les parcours de vie des Ouagalais." In Peuplement de Onagadongou et développement urbain, ed. F. Boyer and D. Delaunay, IRD.

Pasquier-Doumer, Laure. 2012. "Inequality of Opportunity in the Urban Labor Market in West Africa." Revue d'Economie du Développement 26(2):44-66.

Pasquier-Doumer, Laure. 2013. "Intergenerational transmission of self-employed status in the informal sector: a constrained choice or better income prospects? Evidence from seven WestAfrican countries." Journal of African Economies 22(1):73-111.

Parrado, Eric, Asena Caner, and Edward N. Wolff. 2007. "Occupational and Industrial Mobility in the United States." Labour Economics 14:435-455.

Platteau, Jean-Philippe. 2000. Institutions, Social Norms and Economic Development. Amsterdam: Harwood Academic Publishers.

Poulain, Michel, Benoît Riandey, and Jean-Marie Firdion. 1992. "Data From a Life History Survey and from the Belgian Population Register: A Comparison." Population: An English Selection 4:77-96.

Whitehouse, Bruce. 2011. "Enterprising Strangers: Social Capital and Social Liability Among African Migrant Traders." International Journal of Social Inquiry 4(1):93-111. 
Appendix

Table A1. Principal component analysis (PCA) of social network characteristics

\begin{tabular}{lllll}
\hline Factors & Eigenvalues & Difference & Proportion & Cumulative \\
\hline Factor1 & 2.86287 & 0.33255 & 0.2863 & 0.2863 \\
Factor2 & 2.53032 & 1.33877 & 0.2530 & 0.5393 \\
Factor3 & 1.19155 & 0.14585 & 0.1192 & 0.6585 \\
Factor4 & 1.04571 & 0.09374 & 0.1046 & 0.7630 \\
Factor5 & 0.95197 & 0.27014 & 0.0952 & 0.8582 \\
Factor6 & 0.68183 & 0.26611 & 0.0682 & 0.9264 \\
Factor7 & 0.41572 & 0.21282 & 0.0416 & 0.9680 \\
Factor8 & 0.20290 & 0.12171 & 0.0203 & 0.9883 \\
Factor9 & 0.08120 & 0.04527 & 0.0081 & 0.9964 \\
Factor10 & 0.03592 &. & 0.0036 & 1.0000 \\
\hline \multicolumn{2}{c}{ Source: Ouaga2009 survey, authors' calculation. } & &
\end{tabular}

Table A2. Pairwise correlation coefficients between PCA factors, kinship network and individual characteristics

\begin{tabular}{|c|c|c|c|c|c|c|}
\hline \multicolumn{7}{|c|}{ Factor } \\
\hline & Factor 1 & 2 & Factor 3 & Factor 4 & Factor 5 & Factor 6 \\
\hline & $\begin{array}{l}\text { Resources } \\
\text { in human } \\
\text { capital } \\
\text { embedded } \\
\text { in the } \\
\text { network }\end{array}$ & $\begin{array}{l}\text { Distance to } \\
\text { the origin } \\
\text { locality/ } \\
\text { Weak ties } \\
\text { with } \\
\text { kinship }\end{array}$ & $\begin{array}{c}\text { Fragmen- } \\
\text { tation of } \\
\text { the } \\
\text { siblings } \\
\text { /Weak ties } \\
\text { with } \\
\text { siblings }\end{array}$ & $\begin{array}{l}\text { Size of } \\
\text { the } \\
\text { sibling } \\
\text { network }\end{array}$ & $\begin{array}{l}\text { Occupational } \\
\text { resources } \\
\text { embedded in } \\
\text { the network }\end{array}$ & $\begin{array}{l}\text { Reciprocity } \\
\text { / Strong } \\
\text { ties with } \\
\text { kinship }\end{array}$ \\
\hline \multicolumn{7}{|l|}{ Social network characteristics } \\
\hline $\mathrm{N}$ siblings & $0.2806^{*}$ & $0.0780^{*}$ & $0.1987 *$ & $0.9077 *$ & $0.1662^{*}$ & 0.0339 \\
\hline Siblings'average years of schooling & $0.9723 *$ & $0.1621 *$ & -0.0371 & $0.2551^{*}$ & $0.3448^{*}$ & 0.0220 \\
\hline Siblings'max years of schooling & $0.9627 *$ & $0.1788^{*}$ & 0.0195 & $0.3886^{*}$ & $0.3749 *$ & 0.0434 \\
\hline Siblings in public sector & $0.4628 *$ & $0.1295^{*}$ & 0.0364 & $0.2092 *$ & $0.9546 *$ & 0.0282 \\
\hline $\begin{array}{l}\text { Distance from the birth place to Ouaga } \\
\text { (hours) }\end{array}$ & $0.1406^{*}$ & $0.9902 *$ & $0.4153^{*}$ & -0.0556 & $0.1248^{*}$ & 0.0606 \\
\hline $\begin{array}{l}\text { Distance from the birth place to Ouaga } \\
\text { (CFA) }\end{array}$ & $0.1848^{*}$ & $0.9905 *$ & $0.3963 *$ & -0.0123 & $0.1168^{*}$ & 0.0613 \\
\hline Siblings' remoteness to Ouaga & $-0.1393^{*}$ & $0.3446^{*}$ & $0.8959 *$ & $-0.1847^{*}$ & $0.1768^{*}$ & 0.0164 \\
\hline $\mathrm{N}$ siblings in Ouaga & $0.3250^{*}$ & $-0.2436 *$ & $-0.5211 *$ & $0.8136 *$ & -0.0053 & 0.0039 \\
\hline $\mathrm{N}$ siblings abroad & $0.1726^{*}$ & $0.3709 *$ & $0.8228 *$ & $0.2087^{*}$ & $-0.1187 *$ & -0.0256 \\
\hline Visit to parents & 0.0356 & 0.0600 & -0.0049 & 0.0305 & 0.0300 & 0.9995 \\
\hline \multicolumn{7}{|l|}{ Individual characteristics } \\
\hline Aged 26-35 years & $0.1286^{*}$ & 0.0125 & 0.0203 & $0.1455^{*}$ & 0.0045 & -0.0133 \\
\hline Aged 45 years and more & $-0.2364^{*}$ & -0.0087 & -0.0015 & $-0.2959 *$ & 0.0262 & 0.0458 \\
\hline Islam & $-0.2136^{*}$ & 0.0478 & -0.0142 & -0.0497 & $-0.1276^{*}$ & -0.0267 \\
\hline Moore & $-0.2144^{*}$ & $-0.3654 *$ & $-0.2224^{*}$ & 0.0179 & $-0.1409 *$ & -0.0570 \\
\hline Born in Ouaga & $0.2107^{*}$ & $-0.5455^{*}$ & $-0.3746^{*}$ & $0.2533^{*}$ & $-0.1166^{*}$ & -0.0593 \\
\hline Primary school & 0.0377 & -0.0488 & $-0.1178^{*}$ & $0.1123^{*}$ & $-0.0712^{*}$ & 0.0174 \\
\hline Lower secondary school & $0.2069 *$ & 0.0103 & -0.0354 & $0.0731^{*}$ & 0.0239 & -0.0346 \\
\hline Higher secondary school and above & $0.4737 *$ & $0.2275^{*}$ & $0.1273^{*}$ & $0.1467^{*}$ & $0.2965^{*}$ & 0.0681 \\
\hline
\end{tabular}


Table A3. Hazard regression results (full table)

\begin{tabular}{|c|c|c|c|c|c|c|c|c|c|c|c|c|}
\hline & \multicolumn{4}{|c|}{ Unemployment to Employment } & \multicolumn{4}{|c|}{ Wage Employment to Self-Employment } & \multicolumn{4}{|c|}{ Self-Employment to Wage Employment } \\
\hline VARIABLES & $\begin{array}{c}(1) \\
\text { Non-frailty } \\
\text { model }\end{array}$ & $\begin{array}{c}(2) \\
\text { Non-frailty } \\
\text { model }\end{array}$ & $\begin{array}{l}\quad(3) \\
\text { Frailty } \\
\text { model }\end{array}$ & $\begin{array}{c}\text { (4) } \\
\text { Frailty model }\end{array}$ & $\begin{array}{c}\text { (1) } \\
\text { Non-frailty } \\
\text { model }\end{array}$ & $\begin{array}{c}(2) \\
\text { Non-frailty } \\
\text { model }\end{array}$ & $\begin{array}{l}\quad(3) \\
\text { Frailty } \\
\text { model }\end{array}$ & $\begin{array}{c}\text { (4) } \\
\text { Frailty model }\end{array}$ & $\begin{array}{c}(1) \\
\text { Non-frailty } \\
\text { model }\end{array}$ & $\begin{array}{c}\text { (2) } \\
\text { Non-frailty } \\
\text { model }\end{array}$ & $\begin{array}{l}\text { (3) } \\
\text { Frailty } \\
\text { model }\end{array}$ & $\begin{array}{l}\quad(4) \\
\text { Frailty } \\
\text { model }\end{array}$ \\
\hline \multicolumn{13}{|l|}{$\begin{array}{l}\text { Individual } \\
\text { characteristics }\end{array}$} \\
\hline Muslim & $\begin{array}{c}0.190 \\
(0.230)\end{array}$ & $\begin{array}{c}0.203 \\
(0.230)\end{array}$ & $\begin{array}{c}0.271 \\
(0.249)\end{array}$ & $\begin{array}{l}0.284 \\
(0.233)\end{array}$ & $\begin{array}{c}0.131 \\
(0.195)\end{array}$ & $\begin{array}{c}0.141 \\
(0.195)\end{array}$ & $\begin{array}{l}0.0967 \\
(0.207)\end{array}$ & $\begin{array}{l}0.0959 \\
(0.235)\end{array}$ & $\begin{array}{l}-0.351 \\
(0.218)\end{array}$ & $\begin{array}{l}-0.351 \\
(0.218)\end{array}$ & $\begin{array}{l}-0.360 \\
(0.237)\end{array}$ & $\begin{array}{l}-0.367 \\
(0.225)\end{array}$ \\
\hline Moore & $\begin{array}{l}0.169 \\
(0.268)\end{array}$ & $\begin{array}{c}0.211 \\
(0.274)\end{array}$ & $\begin{array}{l}0.176 \\
(0.278)\end{array}$ & $\begin{array}{l}0.214 \\
(0.268)\end{array}$ & $\begin{array}{l}0.252 \\
(0.294)\end{array}$ & $\begin{array}{l}0.233 \\
(0.297)\end{array}$ & $\begin{array}{l}0.260 \\
(0.264)\end{array}$ & $\begin{array}{c}0.231 \\
(0.297)\end{array}$ & $\begin{array}{l}0.189 \\
(0.359)\end{array}$ & $\begin{array}{l}0.198 \\
(0.362)\end{array}$ & $\begin{array}{l}0.0786 \\
(0.343)\end{array}$ & $\begin{array}{l}0.102 \\
(0.368)\end{array}$ \\
\hline Primary school & $\begin{array}{l}0.731^{* *} \\
(0.333)\end{array}$ & $\begin{array}{c}0.711^{* *} \\
(0.329)\end{array}$ & $\begin{array}{c}0.445 \\
(0.345)\end{array}$ & $\begin{array}{c}0.436 \\
(0.342)\end{array}$ & $\begin{array}{l}-0.0574 \\
(0.246)\end{array}$ & $\begin{array}{l}-0.0813 \\
(0.247)\end{array}$ & $\begin{array}{l}-0.0802 \\
(0.265)\end{array}$ & $\begin{array}{l}-0.103 \\
(0.278)\end{array}$ & $\begin{array}{c}0.559^{* *} \\
(0.274)\end{array}$ & $\begin{array}{c}0.553^{* *} \\
(0.275)\end{array}$ & $\begin{array}{l}0.530 * \\
(0.313)\end{array}$ & $\begin{array}{l}0.521 * \\
(0.307)\end{array}$ \\
\hline $\begin{array}{l}\text { Lower secondary } \\
\text { school }\end{array}$ & $\begin{array}{l}0.0967 \\
(0.419)\end{array}$ & $\begin{array}{l}0.0521 \\
(0.419)\end{array}$ & $\begin{array}{c}-0.0421 \\
(0.438)\end{array}$ & $\begin{array}{l}-0.0767 \\
(0.429)\end{array}$ & $\begin{array}{l}-0.586 \\
(0.393)\end{array}$ & $\begin{array}{l}-0.599 \\
(0.393)\end{array}$ & $\begin{array}{l}-0.418 \\
(0.388)\end{array}$ & $\begin{array}{l}-0.419 \\
(0.386)\end{array}$ & $\begin{array}{c}0.758 \\
(0.461)\end{array}$ & $\begin{array}{l}0.720 \\
(0.468)\end{array}$ & $\begin{array}{c}1.124^{* *} \\
(0.473)\end{array}$ & $\begin{array}{l}1.067^{* *} \\
(0.486)\end{array}$ \\
\hline $\begin{array}{l}\text { Higher secondary } \\
\text { school \& above }\end{array}$ & $\begin{array}{c}0.847^{* *} \\
(0.417)\end{array}$ & $\begin{array}{l}0.796^{*} \\
(0.416)\end{array}$ & $\begin{array}{l}0.649 \\
(0.469)\end{array}$ & $\begin{array}{c}0.620 \\
(0.450)\end{array}$ & $\begin{array}{c}-1.027^{* *} \\
(0.401)\end{array}$ & $\begin{array}{c}-1.054^{* * *} \\
(0.399)\end{array}$ & $\begin{array}{c}-0.913^{* *} \\
(0.403)\end{array}$ & $\begin{array}{c}-0.911 * * \\
(0.449)\end{array}$ & $\begin{array}{l}0.967 \\
(0.613)\end{array}$ & $\begin{array}{l}0.926 \\
(0.616)\end{array}$ & $\begin{array}{l}1.531^{* *} \\
(0.623)\end{array}$ & $\begin{array}{l}1.445^{* *} \\
(0.656)\end{array}$ \\
\hline $\begin{array}{l}\text { Potential experience } \\
\text { (years) }\end{array}$ & $\begin{array}{c}0.0659 * * \\
(0.0314)\end{array}$ & $\begin{array}{c}0.0618^{* *} \\
(0.0313)\end{array}$ & $\begin{array}{c}0.0487 * * \\
(0.0213)\end{array}$ & $\begin{array}{c}0.0452^{* * *} \\
(0.0150)\end{array}$ & $\begin{array}{l}0.0253 \\
(0.0254)\end{array}$ & $\begin{array}{l}0.0263 \\
(0.0254)\end{array}$ & $\begin{array}{c}0.0409 * * * \\
(0.0158)\end{array}$ & $\begin{array}{l}0.0428^{* *} \\
(0.0185)\end{array}$ & $\begin{array}{c}0.0637^{* *} \\
(0.0323)\end{array}$ & $\begin{array}{c}0.0649 * * \\
(0.0323)\end{array}$ & $\begin{array}{c}0.0969 * * * \\
(0.0305)\end{array}$ & $\begin{array}{c}0.0984 * * * \\
(0.0213)\end{array}$ \\
\hline $\begin{array}{l}\text { Potential experience } \\
\text { squared }\end{array}$ & $\begin{array}{c}-0.00278^{* * *} \\
(0.000952)\end{array}$ & $\begin{array}{c}-0.00273^{* * *} \\
(0.000944)\end{array}$ & $\begin{array}{c}-0.00217^{* * *} \\
(0.000525)\end{array}$ & $\begin{array}{c}-0.00213^{* * *} \\
(0.000524)\end{array}$ & $\begin{array}{l}-0.000788 \\
(0.000586)\end{array}$ & $\begin{array}{l}-0.000799 \\
(0.000587)\end{array}$ & $\begin{array}{c}-0.000942^{* *} \\
(0.000387)\end{array}$ & $\begin{array}{c}-0.000964^{* *} \\
(0.000390)\end{array}$ & $\begin{array}{l}-0.00114 \\
(0.000708)\end{array}$ & $\begin{array}{l}-0.00113 \\
(0.000709)\end{array}$ & $\begin{array}{l}-0.00162^{* *} \\
(0.000690)\end{array}$ & $\begin{array}{c}-0.00160^{* * *} \\
(0.000503)\end{array}$ \\
\hline $\begin{array}{l}\text { Time since arrival in } \\
\text { Ouaga }\end{array}$ & $\begin{array}{l}0.0166 \\
(0.0143)\end{array}$ & $\begin{array}{l}0.0194 \\
(0.0145)\end{array}$ & $\begin{array}{l}0.0182^{*} \\
(0.0100)\end{array}$ & $\begin{array}{l}0.0198 \\
(0.0131)\end{array}$ & $\begin{array}{c}0.0109 \\
(0.00874)\end{array}$ & $\begin{array}{c}0.00976 \\
(0.00867)\end{array}$ & $\begin{array}{c}0.0137 \\
(0.00878)\end{array}$ & $\begin{array}{c}0.0120 \\
(0.00937)\end{array}$ & $\begin{array}{l}-0.0150 \\
(0.00942)\end{array}$ & $\begin{array}{l}-0.0149 \\
(0.00937)\end{array}$ & $\begin{array}{l}-0.0173^{*} \\
(0.0100)\end{array}$ & $\begin{array}{l}-0.0164 * \\
(0.00964)\end{array}$ \\
\hline $\begin{array}{l}\text { Time since first child } \\
\text { birth }\end{array}$ & $\begin{array}{l}-0.0405^{*} \\
(0.0243)\end{array}$ & $\begin{array}{l}-0.0424 * \\
(0.0244)\end{array}$ & $\begin{array}{c}-0.0522^{* * *} \\
(0.0199)\end{array}$ & $\begin{array}{c}-0.0541^{* *} \\
(0.0239)\end{array}$ & $\begin{array}{c}-0.0599 * * * \\
(0.0174)\end{array}$ & $\begin{array}{c}-0.0591 * * * \\
(0.0174)\end{array}$ & $\begin{array}{c}-0.0621 * * * \\
(0.0172)\end{array}$ & $\begin{array}{c}-0.0619^{* * *} \\
(0.0163)\end{array}$ & $\begin{array}{l}-0.0150 \\
(0.0187)\end{array}$ & $\begin{array}{l}-0.0158 \\
(0.0188)\end{array}$ & $\begin{array}{l}-0.00478 \\
(0.0196)\end{array}$ & $\begin{array}{l}-0.00601 \\
(0.0192)\end{array}$ \\
\hline Agricultural sector & & & & & & & & & $1.175^{* * *}$ & $1.181^{* * *}$ & $1.244 * * *$ & $1.268^{* * *}$ \\
\hline
\end{tabular}




\begin{tabular}{|c|c|c|c|c|c|c|c|c|c|c|c|c|}
\hline \multirow{3}{*}{$\begin{array}{l}\text { Standard of living } \\
\text { index }\end{array}$} & & & & & & & & & $(0.242)$ & $(0.241)$ & $(0.260)$ & $(0.259)$ \\
\hline & 0.163 & 0.143 & 0.0849 & 0.0704 & -0.183 & -0.182 & -0.130 & -0.132 & -0.0711 & -0.0783 & -0.0974 & -0.106 \\
\hline & $(0.157)$ & $(0.155)$ & $(0.156)$ & $(0.154)$ & $(0.126)$ & $(0.127)$ & $(0.130)$ & $(0.170)$ & (0.163) & $(0.162)$ & $(0.181)$ & $(0.179)$ \\
\hline \multirow[t]{2}{*}{ Birth order } & 0.0342 & 0.0495 & 0.00762 & 0.0235 & 0.0525 & 0.0480 & 0.0841 & 0.0798 & -0.0179 & -0.0348 & -0.0699 & -0.0829 \\
\hline & (0.103) & $(0.102)$ & $(0.0905)$ & $(0.0892)$ & $(0.0820)$ & $(0.0818)$ & $(0.0809)$ & $(0.0790)$ & $(0.0940)$ & $(0.0928)$ & $(0.0937)$ & $(0.0907)$ \\
\hline \multirow[t]{2}{*}{ Age } & 0.0103 & 0.0127 & 0.0128 & 0.0157 & 0.0102 & 0.0112 & 0.00573 & 0.00687 & -0.00998 & -0.00871 & $-0.0240 * *$ & $-0.0227 *$ \\
\hline & $(0.0242)$ & $(0.0243)$ & $(0.00835)$ & $(0.0112)$ & $(0.0121)$ & $(0.0121)$ & $(0.0113)$ & $(0.0112)$ & $(0.0145)$ & $(0.0144)$ & $(0.0112)$ & $(0.0120)$ \\
\hline \multirow[t]{2}{*}{ Devaluation dummy } & 0.0186 & 0.0128 & -0.0627 & -0.0649 & -0.171 & -0.167 & -0.370 & -0.376 & -0.0197 & 0.00169 & -0.164 & -0.126 \\
\hline & $(0.253)$ & $(0.256)$ & $(0.240)$ & $(0.242)$ & $(0.289)$ & $(0.289)$ & $(0.297)$ & $(0.327)$ & $(0.324)$ & $(0.323)$ & $(0.320)$ & $(0.315)$ \\
\hline $\begin{array}{l}\text { Family network } \\
\text { characteristics }\end{array}$ & \multicolumn{4}{|c|}{ See Table 3} & \multicolumn{4}{|c|}{ See Table 3} & \multicolumn{4}{|c|}{ See Table 3} \\
\hline \multirow[t]{2}{*}{ Constant } & $-4.043^{* * *}$ & $-3.737 * * *$ & $-4.025 * * *$ & $-3.662^{* * *}$ & $-4.729 * * *$ & $-4.868^{* * *}$ & $-4.749 * * *$ & $-5.061^{* * *}$ & $-5.513^{* * *}$ & $-5.353^{* * *}$ & $-5.245^{* * *}$ & $-5.311 * * *$ \\
\hline & $(0.781)$ & $(0.703)$ & $(0.329)$ & $(0.356)$ & $(0.753)$ & $(0.637)$ & $(0.518)$ & $(0.312)$ & $(0.910)$ & $(0.758)$ & $(0.492)$ & $(0.518)$ \\
\hline \multirow[t]{2}{*}{ ln_varg } & & & -13.83 & -13.68 & & & -13.89 & -14.72 & & & -13.67 & -14.02 \\
\hline & & & $(380.0)$ & (320.6) & & & (551.4) & $(1,042)$ & & & (447.4) & (544.0) \\
\hline Observations & 1324 & 1324 & 1324 & 1324 & 10544 & 10544 & 10544 & 10544 & 10726 & 10726 & 10726 & 10726 \\
\hline
\end{tabular}

Source: Ouaga2009 survey, authors' calculation.

Note: Standard errors in parentheses, ${ }^{* * *} \mathrm{p}<0.01,{ }^{* *} \mathrm{p}<0.05,{ }^{*} \mathrm{p}<0.10$. 